\title{
Clomiphene Citrate and Oocyte Quality
}

\author{
Shail K Chaube ${ }^{1 *}$, Meenakshi Tiwari ${ }^{1}$, Anumegha Gupta ${ }^{1}$, Alka Sharma ${ }^{1}$, Shilpa Prasad ${ }^{1}$, Ashutosh N Pandey ${ }^{1}$, \\ Pramod K Yadav ${ }^{1}$, Sabana Khatun ${ }^{1}$ and Tulsidas G Shrivastav ${ }^{2}$ \\ ${ }^{1}$ Department of Zoology, Institute of science Banaras Hindu University, Varanasi-221005, India \\ ${ }^{2}$ Department of Reproductive Biomedicine, National Institute of Health and Family Welfare, New Delhi-110067,India
}

Submission: May 15, 2017; Published: July 05, 2017

*Corresponding author: Shail K Chaube, Cell Physiology Laboratory, Department of Zoology, Institute of Science, Banaras Hindu University, Varanasi-221005, India, Tel: 091-542-6702516; Fax: 091-542-2368174;Email: shailchaubey@gmail.com; shailchaube@bhu.ac.in

\begin{abstract}
The clomiphene citrate (CC) is a first line of medicine used for ovulation induction in women worldwide. CC has good ovulation induction ability in anovulatory women but the pregnancy rate is very poor. This discrepancy might be due to the anti-estrogenic effect of CC at various level including ovary and oocytes. The hypoestrogenic conditions due to CC treatment inhibit follicular growth and development, induce susceptibility of oocytes towards apoptosis and deteriorate oocyte quality after ovulation. CC induces reactive oxygen species (ROS) mediated granulosa cells as well as oocyte apoptosis within the follicle of the ovary. Apoptosis deteriorates oocyte quality and thereby reproductive outcome. Supplementation of estradiol $17 \beta$ or natural antioxidant such as melatonin prevents anti-estrogenic effects of CC and improves oocyte quality by scavenging CC induced generation of ROS. Thus, we propose that the supplementation of estradiol $17 \beta$ and/or melatonin along with CC may be beneficial to overcome the anti-estrogenic effect of CC during infertility management in human.

Keywords: Clomiphene citrate; Ovulation induction; ROS; Apoptosis; Oocyte quality

List of Abbreviations: ROS: Reactive Oxygen Species; CC: Clomiphene Citrate; ER: Estrogen Receptors; GnRH: Gonadotropin-Releasing Hormone; M-II: Metaphase-II; $\mathrm{H}_{2} \mathrm{O}_{2}$ : Hydrogen Peroxide; ART: Assisted Reproductive Technology
\end{abstract}

\section{Introduction}

Ovary is a dynamic organ and generates excess amount of reactive oxygen species (ROS) during follicular growth, development, maturation and ovulation [1]. The increased level of ROS is scavenged by antioxidant systems [2]. A moderate increase of ROS could be beneficial for oocyte meiotic maturation and reproductive outcome [3-5]. Overproduction of ROS or depletion of enzymatic antioxidant systems causes oxidative stress [2].

Anovulation is one of the major causes of reproductive failure in sub-fertile and infertile women [6,7]. In the absence of other reproductive problems, successful ovulation induction and good quality oocyte often restores normal fertility in human [8]. In a common clinical practice, gonadotropins are used to stimulate ovary in infertile or subfertile women $[9,10]$. However, antiestrogens are widely used to induce ovulation in these patients. Clomiphene citrate (CC) is a non-steroidal ovulation-inducing drug that has been used in humans for more than 40 years $[11,12]$. Ovarian stimulation by gonadotropins is an expensive treatment. CC is an inexpensive, safe and effective alternative to gonadotropins [11].

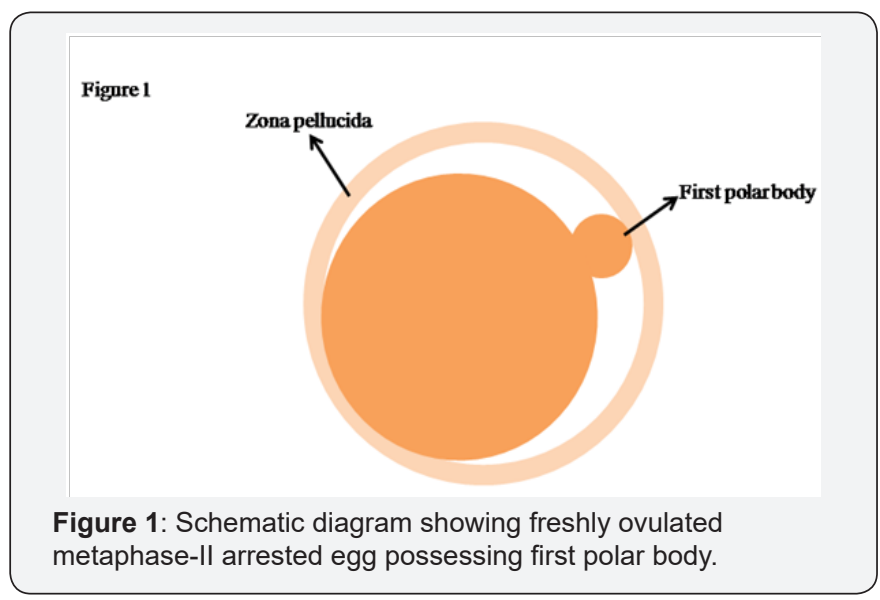

For ovulation induction, CC has been used as a first line of medicine [12]. It is similar to estrogen and thus binds to estrogen receptors (ER) [13]. It triggers hypothalamic gonadotropin- 


\section{Global Journal of Reproductive Medicine}

releasing hormone $(\mathrm{GnRH})$ secretion that stimulates release of pituitary gonadotropins [14]. Pituitary gonadotropins surge trigger growth and development of ovarian follicles $[13,15]$. CC treatment generates dominant follicle and results in the ovulation of metaphase-II (M-II) arrested oocytes required for successful fertilization in various assisted reproductive technology (ART) programs (Figure 1). Although CC has been used for ovulation induction widely, the possible mechanism of its action at the level of ovary still remains ill understood.

In spite of having good ovulation induction ability of CC $(60 \%$ - $85 \%)$, the pregnancy rate is much lower $(10 \%-20 \%)[10,16]$. The higher incidence of miscarriage has been reported in the conception cycle after CC treatment [17]. Such a discrepancy could be due to anti-estrogenic effect of CC, particularly at the level of ovary, cervical mucus and endometrium $[17,18]$. The anti-estrogenic effects of CC may result apoptosis in granulosa cells and oocyte in ovary [6]. Studies suggest that CC induces apoptosis in human granulosa cells cultured in vitro [19]. CC induces granulosa cell apoptosis that reduces estradiol $17 \beta$ level in the ovary of rat $[20,21]$ as well as in monkey [22].

The CC induced hypoestrogenic conditions may induce generation of ROS [6]. Animal studies suggest that CC treatment increases hydrogen peroxide $\left(\mathrm{H}_{2} \mathrm{O}_{2}\right)$ level and reduces catalase activity in rat [21]. The increased level of ROS induces overexpression of bax protein and thereby DNA fragmentation both in granulosa cells and oocytes [20,21,24-32]. Granulosa cell apoptosis results in reduced estradiol $17 \beta$ level in ovary $[21,24$ $26]$. The reduced level of estradiol $17 \beta$ may deteriorate oocyte quality by inducing susceptibility of oocytes towards apoptosis. These oocytes are not of good quality and their use reduces ART outcome.

The anti-estrogenic condition due to CC treatment is one of the major side effects that affects the development and maturation of oocytes in the ovary and reduces oocyte quality after ovulation. To overcome the anti-estrogenic effect of CC, supplementation of exogenous estradiol $17 \beta$ has been recommended [20,23,33]. This is further supported by the observations that the exogenous estradiol $17 \beta$ prevents apoptosis and thereby deterioration of oocyte quality $[20,23]$.

The antiestrogenic effect of CC can also be prevented by the supplementation of a naturally occurring antioxidant such as melatonin [21]. Melatonin scavenges free radicals [34], induces superoxide dismutase [35] and glutathione peroxidase activities to prevent oxidative damage in human [36]. Animal studies suggest that melatonin induces catalase activity, reduces $\mathrm{H}_{2} \mathrm{O}_{2}$ level and prevents CC-induced oocyte apoptosis [21].

\section{Conclusion}

Based on existing clinical as well as animal studies, we conclude that use of either estradiol $17 \beta$ or melatonin along with $\mathrm{CC}$ would be beneficial to overcome the anti-estrogenic effects of $\mathrm{CC}$ at the level of ovary during infertility management in human.

\section{Acknowledgement}

Authors are thankful to Department of Science and Technology (EMR/2014/000702), New Delhi, India, for financial assistance.

\section{Conflict of Interest}

The authors declare that no conflict of interest exists.

\section{References}

1. Tiwari M, Chaube SK (2016) Moderate increase of reactive oxygen species triggers meiotic resumption in rat follicular oocytes. J Obstet Gynaecol Res 42(5): 536-546.

2. Agarwal A, Gupta S, Sharma R (2005) Oxidative stress and its implications in female infertility-A clinician's perspective. RBM Online 11(5): 641-650.

3. Chaube SK, Khatun S, Misra SK, Shrivastav TG (2008) Calcium ionophore-induced egg activation and apoptosis are associated with the generation of intracellular hydrogen peroxide. Free Radic Res 42(3): 212-220.

4. Tripathi A, Khatun S, Pandey AN, Mishra SK, Chaube R, et. al. (2009) Intracellular levels of hydrogen peroxide and nitric oxide in oocyte at various stages of meiotic cell cycle and apoptosis. Free Radic Res 43(3): 287-294.

5. Tripathi A, Kumar KV, Chaube SK (2010) Meiotic cell cycle arrest in mammalian oocytes. J Cell Physiol 223(3): 592-600.

6. Chaube SK, Shrivastav TG, Prasad S, Tiwari M, Tripathi A, et al. (2014) Clomiphene citrate induces ROS-mediated apoptosis in mammalian oocytes. OJ Apo 3(3): 52-58.

7. Hassan ZB (2017) Comparison between tamoxifen and clomiphene citrate for induction of ovulation and successful conception in polycystic ovarian syndrome. IJRCOG 4(5): 1349-1352.

8. Katsikis I, Kita M, Karkanaki A, Prapas N, Panidis D (2006) Anovulation and ovulation induction. Hippokratia 10(3): 120-127.

9. Melo AS, Ferriani RA, Navarro PA (2015) Treatment of infertility in women with polycystic ovary syndrome: Approach to clinical practice. Clinics 70(11): 765-769.

10. Pourali L, Ayati S, Tavakolizadeh S, Soleimani H, Sani FT (2017) Clomiphene citrate versus letrozole with gonadotropins in intrauterine insemination cycles: A randomized trial. Int J Reprod Biomed 15(1): 49-54.

11.Tiwari N, Gupta S, Satwik R, Majumdar A, Mittal S (2015) Clomiphene based ovarian stimulation in a commercial donor program. J Hum Reprod Sci 8(3): 142-145.

12.Weller A, Daniel S, Koren G, Lunenfeld E, Levy A (2017) The fetal safety of clomiphene citrate: A population-based retrospective cohort study. BJOG.

13. Mitwally MF, Casper RF (2006) Review: Aromatase inhibitors for ovulation induction. J Clin Endocrinol Metab 91(3): 760-71.

14. Munhoz RR, Pereira AA, Sasse AD, Hoff PM, Traina TA, et. al. (2016) Gonadotropin-releasing hormone agonists for ovarian function preservation in premenopausal women undergoing chemotherapy for early-stage breast cancer: A systematic review and meta-analysis. JAMA Oncol 2(1): 65-73.

15. Kumar P, Sait SF (2011) Luteinizing hormone and its dilemma in ovulation induction. J Hum Reprod Sci 4(1): 2-7. 


\section{Global Journal of Reproductive Medicine}

16. Fisher SA, Reid RL, Vugt DAV, Casper RF (2002) A randomized doubleblind comparison of the effects of clomiphene citrate and the aromatase inhibitor letrozole on ovulatory function in normal women. Fertil Steril 78 (2): 280-285.

17. Nakagawa K, Kaneyama M, Nishi Y, Sugiyama R, Motoyama H, et al. (2015) Clomiphene citrate affects the receptivity of the uterine endometrium. Reprod Med Biol 14: 73-78.

18. Li TC, Warren MA, Murphy C (1999) A prospective, randomized, crossover study comparing the effects of clomiphene citrate and cytophenil on endometrial morphology in the luteal phase of normal fertile women. Fertil Steril 71(4): 639-644.

19. Schwartz LB, Brezinski A, Laufer N (1993) The effects of clomiphene citrate isomers on human granulosa-lutein cells in culture. Gynaecol Endocrinol 7(4): 229-233.

20. Chaube SK, Prasad PV, Thakur SC, Shrivastav TG (2005) Estradiol protects clomiphene citrate-induced apoptosis in ovarian follicular cells and ovulated cumulus-oocyte complexes. Fertil Steril 84(Suppl 2): 1163- 1172.

21. Tripathi A, Prem Kumar KV, Pandey AN, Khatun S, Mishra SK, et al. (2011) Melatonin protects against clomiphine citrate-induced generation of hydrogen peroxide and morphological apoptotic changes in rat eggs. Eur J Pharmacol 667(1-3): 419-424.

22. Marut EL, Hodgen GD (1982) Anti-estrogenic action of high-dose clomiphene in primates: Pituitary augmentation but with ovarian attenuation. Fertil Steril 38(1): 100-104.

23. Chaube SK, Prasad PV, Tripathi V, Shrivastav TG (2006) Clomiphene citrate inhibits gonadotropin-induced ovulation by reducing cyclic adenosine 3',5'-cyclic monophosphate and prostaglandin e2 levels in rat ovary. Fertil Steril 86(Suppl 4): 1106-1111.

24. Chaube SK, Prasad PV, Thakur SC, Shrivastav TG (2005) Hydrogen peroxide modulates meiotic cell cycle and induces morphologica features characteristic of apoptosis in rat oocytes cultured in vitro. Apoptosis 10(4): 863-874.

25. Tripathi A, Shrivastav TG, Chaube SK (2013) An increase of granulosa cell apoptosis mediates aqueous neem (Azadirachta indica) leaf extract induced oocyte apoptosis in rat. Int J Appl Basic Med Res 3(1): 27-36.

26. Chaube SK, Shrivastav TG, Tiwari M, Prasad S, Tripathi A, et al. (2014)
Neem (Azadirachta indica L.) leaf extract deteriorates oocyte quality by inducing ROS-mediated apoptosis in mammals. Springer Plus 3: 464.

27. Tiwari M, Prasad S, Tripathi A, Pandey AN, Ali I, et al. (2015) Apoptosis in mammalian oocytes: A review. Apoptosis 20(8): 1019-1025.

28. Tiwari M, Prasad S, Tripathi A, Pandey AN, Singh AK, et al. (2016) Involvement of reactive oxygen species in meiotic cell cycle regulation and apoptosis in mammalian oocytes. Reactive Oxygen Species 1(2): 110-116.

29. Prasad S, Tiwari M, Pandey AN, Shrivastav TG, Chaube SK (2016) Impact of stress on oocyte quality and reproductive outcome. J Biomed Sci 23: 36

30. Tiwari M, Prasad S, Shrivastav TG, Chaube SK (2017) Calcium signaling during meiotic cell cycle regulation and apoptosis in mammalian oocytes. J Cell Physiol 232(5): 976-981.

31. Tiwari M, Tripathi A, Chaube SK (2017) Presence of encircling granulosa cells protects against oxidative stress-induced apoptosis in rat eggs cultured in vitro. Apoptosis 22(1): 98-107.

32. Tripathi A, Chaube SK (2015) Roscovitine inhibits extrusion of second polar body and induces apoptosis in rat eggs cultured in vitro. Pharmacol Report 67(5): 866-874.

33. Gerli S, Gholami H, Manna A (2000) Use of ethinyl estradiol to reverse the anti-estrogenic effects of clomiphene citrate in patients undergoing intrauterine insemination: A comparative, randomized study. Fertil Steril 73(1): 85-89.

34. Tan DX, Manchester LC, Terron MP, Flores LJ, Reiter RJ (2007) One molecule, many derivatives: A never-ending interaction of melatonin with reactive oxygen and nitrogen species? J Pineal Res 42(1): 28-42.

35. Ozturk G, Coskun S, Erbas D, Hasanoglu E (2000) The effect of melatonin on liver superoxide dismutase activity, serum nitrate and thyroid hormone levels. Jpn J Physiol 50(1): 149-153.

36. Reiter RJ, Tan DX, Manchester LC, Paredes SD, Mayo JC, et al. (2009) Melatonin and reproduction revisited. Biol Reprod 81(3): 445-456.

\section{Your next submission with Juniper Publishers will reach you the below assets}

- Quality Editorial service

- Swift Peer Review

- Reprints availability

- E-prints Service

- Manuscript Podcast for convenient understanding

- Global attainment for your research

- Manuscript accessibility in different formats

( Pdf, E-pub, Full Text, Audio)

- Unceasing customer service

Track the below URL for one-step submission https://juniperpublishers.com/online-submission.php 